\section{Gén eros}

Multidisciplinary Journal of Gender: Studies

\section{Hipatia Press \\ www.hipatiapress.com}

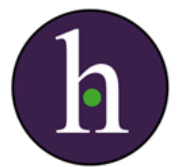

Instructions for authors, subscriptions and further details:

http://generos.hipatiapress.com

Gender-Awareness amongst Brazilian Children Enrolled in Primary Education: Implications for Women's Rights \& Equality

Erick da Luz Scherf ${ }^{1}$

Maria de Lourdes Alves Lima Zanatta ${ }^{1}$

Estefania Tumenas Mello ${ }^{1}$

1) University of Itajaí Valley, Brazil.

Date of publication: February 25th, 2020

Edition period: February-June 2020

To cite this article: da Luz Scherf, E., Alves Lima Zanatta, M L., Tumenas Mello, E. (2020). Gender-Awareness amongst Brazilian Children Enrolled in Primary Education: Implications for Women's Rights \& Equality. Multidisciplinary Journal of Gender Studies, 9(1), 25-50. doi: 10.17583/generos.2020.4865

To link this article: http://dx.doi.org/10.17583/generos.2020.4865

PLEASE SCROLL DOWN FOR ARTICLE

The terms and conditions of use are related to the Open Journal System and to Creative Commons Attribution License (CC-BY). 


\section{Gender-Awareness amongst Brazilian Children Enrolled in Primary Education: Implications for Women's Rights \& Equality}

Erick da Luz Scherf

University of Itajaí Valley

Estefania Tumenas Mello

University of Itajaí Valley
Maria de Lourdes Alves Lima Zanatta

University of Itajaí Valley

\section{Abstract}

The general objectives of this article were, one the one hand, to investigate what are the perceptions of Brazilian children enrolled in primary education over gender-assigned roles and the place of women in society. And on the other hand, to analyse what could be the impacts of their answers on the foreseeable future of women's rights and equality in contemporary Brazil. This research was drawn from a qualitative approach and our research instrument was composed of data collection and data analysis through the use of surveys. Our main conclusions were that gender dynamics within the family core influences a lot the perception of children over gender hierarchies, which can result in repeating patterns of gender inequality and in reinforcing pre-assigned roles for women in society. Thus, the role of gender education is paramount in the task of helping these children challenge and question this unequal and often unjust power balance that takes place in their households. When asked about what they considered to be the role of women in society, the majority of the children surveyed answered that women should work and be responsible for activities such as taking care of the family or doing housework. This vision imposes a burden upon women to follow certain social roles as well as limits the future visions they have for themselves.

Keywords: children, primary education, gender education, gender equality, women’s rights, Brazil 


\section{Conciencia de género entre niños y niñas brasileños estudiantes de Educación Primaria: implicaciones para los derechos y la igualdad de las mujeres}

Erick da Luz Scherf

University of Itajaí Valley

Estefania Tumenas Mello

University of Itajaí Valley
Maria de Lourdes Alves Lima Zanatta

University of Itajaí Valley

\section{Abstract}

Los objetivos generales de este artículo fueron, por un lado, investigar cuáles son las percepciones de los niños y niñas brasileños estudiantes de Educación Primaria sobre los roles asignados por género y el lugar de la mujer en la sociedad. Y, por otro lado, analizar cuáles podrían ser los impactos de sus respuestas sobre el futuro de los derechos y la igualdad de las mujeres en el Brasil contemporáneo. Esta investigación se basa en un enfoque cualitativo empleando como instrumento de investigación la recopilación de datos y el análisis de datos mediante el uso de encuestas. Nuestras principales conclusiones fueron que la dinámica de género dentro del núcleo familiar influye mucho en la percepción de los niños y niñas sobre las jerarquías de género, lo que puede resultar en patrones repetitivos de desigualdad de género y en el refuerzo de roles preasignados para las mujeres en la sociedad. Por lo tanto, el papel de la educación de género es primordial en la tarea de ayudar a estos niños y niñas a desafiar y cuestionar este equilibrio de poder desigual y a menudo injusto que tiene lugar en sus hogares. Cuando se les preguntó cuál era el papel de las mujeres en la sociedad, la mayoría de niños y niñas encuestados respondieron que las mujeres deberían trabajar y ser responsables de actividades como cuidar a la familia o hacer las tareas del hogar. Esta visión impone una carga sobre las mujeres para seguir ciertos roles sociales, así como limita las visiones futuras que tienen para sí mismas.

Keywords: infancia, educación primaria, educación de género, igualdad de género, derechos de las mujeres, Brasil. 


\section{7 da Luz Scherf, Alves Lima Zanatta, Tumenas Mell - Gender-Awarness amongst Brazilian Children}

W hy should education encompass issues of gender, feminism, race, class, etc.? Such question should probably be preceded by yet another question: what is the aim of education? Pappas and Garrison (1991) state that this latter question should be asked by all those interested in the philosophy of education. According to them, for a very long time, scholars believed that the role of education was to form rational persons: a conceptualization descendent from liberal theories of education (Pappas \& Garrison, 1991). However, this discourse (of the rational mind) which dominated for quite some time the discussions about the aims of education, does not leave any space to discuss about our emotions, instincts, or habits as social practices that influence our "rationality" (Pappas \& Garrison, 1991, p. 298).

The role of formal education is to, according to D'Souza (1992), not only educate people but to guarantee that such education influences (at some level) their behaviours as social beings responsible for social action/change. Therefore, intellectual education should also tackle with sensitivity, problems, and challenges that arise from social reality. Authors from the field of critical pedagogy have offered a great amount of work that leads to this conclusion, with particular focus on issues of social/power inequality (Mayo, 2006; Kincheloe, 2007). Even though critical pedagogy is a large and diverse field of inquiry, "the major aims of these critical approaches to education, diverse though they are, is to develop critical consciousness among the students/learners and to empower them” (Ng, 1995, p. 131, our italics).

However, by the end of the 20th century, many feminist scholars working in the field of education argued that the promises of empowerment coming from critical pedagogy did not translate into equality for women in academics. According to Gottesman (2016), the field of education had been long dominated by male figures, who did not centre the experiences of women or engaged in feminist scholarship in education. Thus, if education should take into account structural inequalities and the need to overcome them, it should start by acknowledging the inequalities within the educational framework itself.

Even though the contemporary scenario is different from the last century one, as women have had more access to higher education and have engaged considerably in academic research, there are still many gaps needed to be fulfilled in order for them to achieve gender equality in education. 
Winslow (2010) shows that women still face many subtle challenges in the academy, especially regarding the allocation of time to teaching and research, as she goes on to analyse gender inequality in payment, as well as faculty members' actual and preferred time allocations to teaching and research. Roos and Gatta (2009) also examine how subtle mechanisms produce inequality for women in academic positions, showing that unequal gender outcomes persist in the academic workplace.

Therefore, the feminist ethos is still needed in education scholarship as well as in pedagogy, in order to recognize the challenges women still face not only in the academy but also in overall society. Alongside that, issues of gender, and gender identity should also be brought into the general discussion about inequality and the role of education. Mayo (2013) states that, even though many believe we live in a "post-gender identity" world, disidentification with students' genders may cause them to be passive towards a world that indeed sees them as gendered.

Thus, there is still a need to develop educational policies that focus on gender equality in education, as society as a whole has not abandoned its gendered views of people. As prior demonstrated by Aikman and Unterhalter (2007), we still live in a world in which education is marked by gender inequalities that cannot be ignored by those involved with critical approaches to education, as even though most countries worldwide have achieved gender parity in primary education, disparities remain, particularly in Sub-Saharan Africa, the Middle East and South Asia (UNICEF, 2018).

In Latin America, despite the fact that women since the 1970s have had more access to education in all levels in the region - as the number of education years amongst adult women grew exponentially from the 1990s up until 2015 (Marchionni, Gasparini \& Edo, 2018) - access to education itself could not transform the structural patters of gender violence in Latin America. That is, even though women are more present in higher education and in the workforce, Latin American women still suffer with different manifestations of gender violence, such as lack of reproductive rights and access to reproductive health; informal and poorly paid employment; low levels of female political participation related to the need for public empowerment; physical and psychological violence, all which seriously undermine the autonomy of women in the region (Seisdedos \& Bonometti, 2010).

Until the 2000s, the majority of Latin American countries did not have specific policies to establish the discussion of gender-related themes in formal 


\section{9 da Luz Scherf, Alves Lima Zanatta, Tumenas Mell - Gender-Awarness amongst Brazilian Children}

education at any level, what prevailed was a homogenizing view that denied gender differences and educational policies did not incorporate gender education into curricula or teacher training programs (Lima, 2016). In Brazil, gender education officially entered the National Plan for Education (PNE) in 1998, and in the following decades, other legislations related to education regulation that contained gender-related issues were also passed (Barreiro \& Martins, 2016). However, in the past three years, many conservative movements tried to mine gender education in the country and have gained space and force, to a point where many professors who dared to discuss gender issues in the classroom have been intimated and silenced by politicians and Christian activists (Reis \& Eggert, 2017).

It is in the face of these challenges in Latin America and in Brazil more specifically, where gender violence still perseveres and conservative movements constantly attack and mine gender education, that this research emerges in order to explore what are the views of children regarding genderassigned roles and the place of women in society. If it is true that children are believed to be major actors in rewriting the future of their nations, the lack of gender education in primary school and henceforth can signify the reproduction of structural patterns of gender inequality. Fortunato and Dias (2018, p. 627) show that in most of the Brazilian educational practices, the "teaching that is propagated in schools does not present rights and conditions of equity for men and women, nor has it implemented actions consistent with the fight against social inequalities". Therefore, there is still a need to access children's perceptions of gender-related issues so specific education policies can be developed, enabling us to challenge traditional and conservative views over gender roles.

\section{The Importance of Gender Discussion in Primary Education}

Matthew According to the World Education Indicators (WEI), developed by UNESCO, Primary Education in Brazil comprises a theoretical starting age of 7 years old for students, and a duration of 4 years of study, which means a regular Brazilian student would finish his or her primary education at 10-11 years of age (UNESCO, 2008). Primary education students were chosen as the focus group for this research because we believe that primary education is the cornerstone of the whole educational system. 
Primary education in Brazil is mandatory by the law and according to the Brazilian Curriculum Guidelines for Primary Education (Diretrizes Curriculares Nacionais para Educação Básica) (hereinafter "Guidelines"), students enrolled in primary education should develop emotional, social and ecological literacy; as well as be aware of the scientific knowledge pertinent to different times, spaces and senses (Brazilian Ministry of Education [MEC], 2013, p. 33). In this sense, at least from a theoretical perspective, primary education in Brazil focuses on literacy not only as of the mere ability to read and write or to have knowledge of specific academic subjects but also the holistic view/account of the social context these students are embedded.

According to the Guidelines, primary education should also provide the students with a formal education that helps them develop their citizenship (MEC, 2013). Citizenship education being a vast field of inquiry as it is, it comprises at least one main goal: the development of good democratic citizens (Schugurensky \& Myers, 2003), which can also entail the empowerment of individuals and groups towards emancipatory change (Schugurensky \& Myers, 2003). Therefore, students leaving primary school should also be able to not only point out the social issues surrounding them but the solutions they would offer to such issues, with the focus being on the active/participatory aspect of citizenship.

In this sense, the discussion of gender-related themes is essential to primary education, considering that it is in this phase that students will be confronted with the ideas and knowledge which will help them shape the perception of the world surrounding them. Bhana (2016, p. 2, our italics) argues that, differently from the simplistic pre-assumed idea of childhood innocence, "the early years of primary schooling are a key site for the production and reproduction of gender and sexuality". Thus, if children are actively invested in gender and sexuality, they should also be confronted with the knowledge and discussions essential to contesting pre-assigned social roles for boys and girls because of their gender identity or sexuality (Bhana, 2016).

Glenda MacNaughton (2000) also argues that many people, including professors themselves, consider that gender does not matter to young children, while evidence has shown that gender education in early childhood has the potentiality to produce gender equity for all in the future. Gill, Esson, and Yuen (2016) address particular issues around girls' education and their 


\section{1 da Luz Scherf, Alves Lima Zanatta, Tumenas Mell - Gender-Awarness amongst Brazilian Children}

findings suggest that beyond the development of academic skills, schools are a central place where girls learn "how to be girls" in a way that is socially accepted (Gill, Esson \& Yuen, 2016, p. 11), which deeply influences the personal views these girls share over their own futures. Thus, gender education plays a key role in defying traditional views of gender-assigned roles and the consequent places girls/women occupy in society.

\section{Women's Rights and Equality through Education}

A lot has been written about the girls' right to education and the positive outcomes of gender equality in the access to education from a variety of different perspectives (United Nations High Commissioner for Human Rights, 2017; Somani, 2017; Campbell, 2016; Lingard, Henry \& Taylor, 2006). However, even though the access to education by girls is a topic of distinct importance, the discussion around the right to education in the context of persistent gender inequalities in Brazil and Latin America in general, has to move beyond the question of access, as the region has made relative progress in this area (UNICEF, 2018). We suggest that gender equality research and policy-making in education should - now more than ever - encompass two intersectional issues: 1) girls' empowerment through and in education; 2) and the strengthening of human rights education, more specifically, women's rights education.

A recent study prepared for the Committee on Women's Rights and Gender Equality (FEMM) of the European Parliament has shown that, beyond access, a number of other factors like poverty, gender stereotypes, and institutional cultures have great impact on educational outcomes of women and girls (McCracken, Unterhalter, Márquez \& Chełstowska, 2015). That is if girls have more access to education but on the other hand, are not provided with the educational policies that aim at tackling gender inequalities rooted in educational institutions and in classroom culture, it is very likely that the perpetuation of gender inequalities through education policy might continue to take place (McCracken, Unterhalter, Márquez \& Chełstowska, 2015).

Solutions are not simple and are far from easy. However, the question of empowerment of women and girls through and in education appears to us as pivotal. Education for women's empowerment means that, through education, women can not only gain control over their own lives, but also be 
aware of their rights, be able to exercise autonomy, and ultimately, be able to question and challenge practices that propagate gender inequality (Aksornkool, 1995, p. 56). Women empowerment through education, therefore, can contribute to not only giving women and girls a sense of selfcontrol and self-worth but provide them with the tools necessary to influence the direction of social change (Bhat, 2015; Tibbitts, 2015).

Another key strategy to guaranteeing women's rights and gender equality through education is educating about, through and for human rights, with special focus given to the struggle of women for fundamental rights and liberties. If Human Rights Education (HRE) serves "as a tool for enabling learners to understand their own rights and to respect the rights of others [...]" (Struthers, 2015, p. 55), educating women and girls about their rights (or the lack of thereof) is essential to fostering gender equality, to empower women, and to guarantee that they exercise their right to participate in public life and to participate in the decision-making processes that shape society (United Nations High Commissioner for Human Rights, 2017, p. 4). Thus, a combination of educational policies that focus on women's empowerment and educational programs for women's rights in the context of HRE seems paramount to overcoming gender inequality and gender-based violence, among other challenges that women and girls still face in their daily lives.

\section{The Politics of Gender Education in Contemporary Brazil}

During the presidency of Luiz Inácio Lula da Silva (2003-2010) (or just "Lula" as he is most famously known by) - the main leader of the Worker's Party (PT) - Brazilian politics changed considerably if not dramatically in terms of gender equality in political parties and state administration: "[Lula] appointed to his cabinet an unprecedented number of women, including the first secretary of state for gender policies, whilst in Congress, the PT achieved twice the female representation of any other party” (Macaulay, 2006, p. 57).

After Lula left office at the end of 2010, the PT managed to elect the first female president in Brazilian republican history: Dilma Roussef. After that, authors even coined the expression "Dilma effect" to evaluate the growing participation of women in politics and civil society organizations not only in Brazil but also in Latin America in general (Jalalzai \& Santos, 2015). According to Jalalzai and Santos (2015), Dilma Roussef as the first female 


\section{3 da Luz Scherf, Alves Lima Zanatta, Tumenas Mell - Gender-Awarness amongst Brazilian Children}

president increased more than Lula and any other previous presidents both descriptive and substantive representation of women in politics.

However, this scenario of hope for gender equality in politics would change drastically in august 2016, when members of Congress performed a Coup D'état, which interrupted the administration of Dilma, who in theory should have governed until 2018 (Braz, 2017; Bastos, 2017). After the Coup, Dilma's ex-vice president, Michel Temer, took over the office of the presidency. In 2016, Temer not only extinguished the Ministries of Women, Racial Equality and Human Rights, he also inaugurated for the first time since 1979 a Cabinet with no women: a fact which led authors and feminist activists to coin the term "machistério" (a compound of the words macho + ministry) to denounce the downfall of public policies for women under Temer's rule (Gonçalves \& Abreu, 2018).

Since then, Brazil has witnessed the growth of a conservative, evangelical movement sponsored mainly by a "new" Brazilian right-wing, which advocated against abortion, LGBT rights and the diversity agenda in education (Finguerut \& Souza, 2018). Since Dilma left office, Brazilian politicians drafted and approved many bills trying to mine gender diversity initiatives in the country, one example is the "Statute of the Family", a bill prepared by a Catholic deputy which defined family as the union between a man and a woman or the community formed by any of their relatives or descendants (Machado, 2018). However, the biggest threat to gender education in the country came about with the bill of law "School Without Party" (Programa Escola Sem Partido), proposed in 2016, which demanded that the discussion of gender issues in the classroom should be permanently prohibited, as written in Article 2 of Project no. 193/2016 in the Federal Senate:

The State will not interfere in the sexual choice of the students nor will it allow any practice capable of compromising, precipitating or directing the natural maturation and development of its personality, in harmony with the respective biological identity of sex, being prohibited, especially, the application of the postulates of the theory or ideology of gender (Guilherme \& Picoli, 2018, p. 8).

The "School Without Party" program amongst other initiatives to mine gender education in Brazil are a result of an ultra-conservative reaction to gender equality policies in education stablished by the Worker's Party in the 
last decades, as argued by Balieiro (2017). The development of such educational policies brought hope that we would be making great strides towards recognizing gender and sexuality differences through education, however, recent years seem to have shown the resurgence of prejudice, intolerance, and misinformation regarding gender and sexuality, with the creation of a political crusade against the so-called "ideology of gender" in schools (Balieiro, 2017; Miskolci \& Campana, 2017).

The election of former congressional representative Jair Bolsonaro for the presidency by the end of 2018 was the epitome of this ultra-conservative movement and became the worst-case scenario for gender equality in politics, in education and in society as a whole. The recently elected far-right Brazilian president is a self-declared homophobe (Phillips \& Kaiser, 2019), who once publicly told a Brazilian congresswoman, Maria do Rosario, that he would not rape her because she was so ugly she did not deserve it (Meredith, 2018). According to Cioccari and Persichetti (2018) Bolsonaro vehemently uses social media to strengthen his image of a "family guy" with religious and conservative values, while in reality, he propagates racist, homophobic and sexist violence.

Bolsonaro, who is "long perceived as a misogynist” (Hunter \& Power, 2019, p. 77), has spent most of his congressional life (around 30 years) advocating not for causes such as housing, education or health, but fierciely protesting against gender equality and gender education policies: "Mr Alencar [a member of Congress] recalled how Mr Bolsonaro took aim at educational materials in 2011 that sought to raise awareness about homophobia and denounced them as an incitement for children to become sexually active and question their gender identities" (Londoño \& Andreoni, 2018, para. 31). In his very short inaugural speech at Congress, the president elected stated that his aim was at uniting the people, cherishing the family, respecting the religions and the Brazilian Christian roots, and at fighting "gender ideology" while preserving "our” values as a nation (National Congress, 2019).

In this sense, taking into account this context of ever-growing misogynist and sexist conservatism in contemporary Brazilian politics and society, gender discussion in primary education appears not only as necessary but as urgent. The attempts to undermine gender education in public schools have one unannounced goal: to reinstate the status quo in favour of men not only in politics but in society more generally. Gender education policies and 


\section{5 da Luz Scherf, Alves Lima Zanatta, Tumenas Mell - Gender-Awarness amongst Brazilian Children}

policies for gender equality in politics, developed under the Workers' Party, have threatened to bring light to the darkest sectors of our patriarchal society, and it is the role of teachers, researchers, and all of those involved with education to guarantee that they continue to do so.

The Community Project "Intergenerational Law \& Transversality" ("Direito Internacional e Transversalidade", in Brazilian Portuguese), from the University of Itajaí Valley (Universidade do Vale do Itajai), in the city of Itajaí-SC (Brazil), played a vital role on the development of this research. The Project aims at developing interdisciplinary actions related to the role of schools and the civil society in defending children's rights, and in order to do that, we also bring into discussion issues of gender, human rights and environmental justice with the help of educational activities developed with children of all ages in schools and other educational entities in different cities throughout the state of SC.

This Community Project exists since 2002, as has made a major quantitative and qualitative impact on the lives and education of many children and communities that had contact with our actions, as demonstrated in previous researches of former members (Ruschel et al., 2018; Oliveira et al., 2014). Therefore, this research is a result of not only the surveys that we performed with children regarding this specific theme but is also a summary of our experiences from educational field-work with children, especially during the year of 2018 and the first semester of 2019.

The aim of this study consists in answering the following research questions: what are the perceptions of Brazilian children enrolled in primary education over gender-assigned roles and the place of women in society? What are the impacts of their answers on the foreseeable future of women's rights and equality in contemporary Brazil? Our surveys took place at different schools and also at non-profit organizations involved with Primary Education located in six (6) different cities in the state of Santa Catarina (SC), Brazil: Itajaí, Balneário Camboriú, Penha, Camboriú, Joaçaba and Brusque.

\section{Method}

This research was drawn from a qualitative approach. As described by Creswell (2014, p. 40) "qualitative research is an approach for exploring and understanding the meaning individuals or groups ascribe to a social or human problem”. Therefore, it seemed to be the most appropriate research approach 
taking into account our research questions. The process of developing qualitative research involves a broad range of questions and procedures, and the data is typically collected in the participant's setting, and the subsequent data analysis is inductively built from particular to general themes (Creswell, 2014).

- Participants: the population that was surveyed is composed by children from different ages (6-11 years of age), enrolled in primary education in the cities of Itajaí, Balneário Camboriú, Penha, Camboriú, Joaçaba and Brusque, in the state of Santa Catarina, Brazil. The total number of participants (P) was twenty-seven (27). The number of boys (b): thirteen (13). The number of girls (g): fourteen (14).

- Data collection: Our research method was composed of data collection and data analysis through the use of surveys. Survey studies ask a group of people questions about their behaviours, attitudes, or opinions towards a specific social phenomenon (Marczyk, DeMatteo \& Festinger, 2005).

The sample was surveyed in person; the students were given about thirty minutes to write down the answers in the questionnaire. All questions were originally written and performed in their mother-tongue, i.e. Brazilian Portuguese, in order for it to be as much inclusive as possible.

For this research, the questions and the students' answers were translated from Brazilian Portuguese to American English and the identities of the schools and the children involved in the survey remained protected (see Box 1). From all the questions originally asked on the survey, we selected only those related to our research objectives, that is, those that had a close relation to gender-related issues.

Box 1 Questionnaire applied to the children interviewed
a) Please state your name, age, sex and the grade you are at school;
b) Who do you live with?
c) Who is employed in your family?
d) What are the tasks you develop at home?
e) What does your father do when he is at home?
f) And what about your mother, what does she do at home?
g) In your opinion, men and women have the same rights? Why?
h) What is the role of women in society? 


\section{7 da Luz Scherf, Alves Lima Zanatta, Tumenas Mell - Gender-Awarness amongst Brazilian Children}

- Data analysis: With the use of surveys, we intend to not merely describe what the participants think, but also to infer more general conclusions over the matter under analysis. In order to do that, we also constructed a brief review of literature, that served as a theoretical base for later data interpretation. Many children could not properly answer all the questions on the survey, and many left incomplete answers or refused to answer some questions, which resulted in a relatively smaller sampling than we predicted.

We also tried to select mainly those children whose parents (or other responsible adults) shared the same household, in order to identify the gender dynamics (i.e. gender and the power relationships) within the family core. Thus, we ended up with a smaller sample than we predicted, which poses a limitation to the development of a large-scale longitudinal research design. However, we believe that this fact does not undermine the importance of the subject or the conclusions we have reached thus far.

\section{Results}

Bringing into evidence children's evaluation of the gender dynamics within their households might help teachers and policy-makers to track down scenarios of unequal power relations between men and women and to identify how education can actually help transform them. The data here discussed is a result of questionnaires answered by twenty-seven (27) children from different ages, enrolled in primary education from various cities in a Brazilian state. Thirteen (13) of them identified as boys and fourteen (14) as girls. All of their identities were preserved. Three (3) of twenty-seven (27) participants lived with a single parent, while the rest, i.e. twenty-four (24), lived with two parents who shared the same household.

Regarding the exercise of paid labour within the family, thirteen (13) children said that only his or her father worked outside the house; thirteen (13) children stated that both of their parents were employed and one (1) child said that only his/her mother was the one working (see Figure 1). Therefore, the results show that in a considerable number of households both parents have a job, however, amongst those children who only one of their two parents worked (which was the case in fourteen [14] households), c. 92\% of the time 
it was the father who was employed. We believe these facts may have had an influence on how the children surveyed perceive gender pre-assigned roles and the subsequent place(s) of women in society.

Figure 1 Employment among the interviewees' parents. Elaborated by the authors.

(13)

Both parents work

\section{Only the father works}

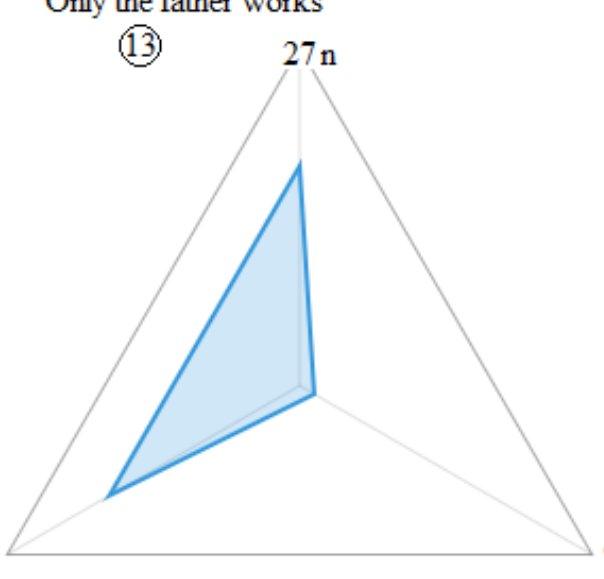

(1)

Only the mother works

\section{Legend:}

$\mathrm{n}$ : total number of participants

Circled numbers: division of employment among the interviewees' parents

Source: Unpublished surveys (2018; 2019).

When asked about the tasks they developed at home, eight (8) of thirteen (13) boys said they help their parents with the housework: e.g., house cleaning, doing the dishes, making the bed, etc. Five (5) of them said they only play or do the homework from school when they are home. When asked the same question, ten (10) of fourteen (14) girls mentioned only housework and no other activity, whilst four (4) of them mentioned that they play and/or do the homework but at the same time help their parents with the housework.

Whilst regarding the tasks which the students' parents develop when they are home, the results are represented in Table 1. 
Table 1 Activities performed by the students' fathers at home. Elaborated by the authors.

\begin{tabular}{lc}
\hline \multicolumn{1}{c}{ Activity description } & Distribution (in percentage) \\
\hline Housework & $11 \%$ \\
"Helps the mother" eventually & $33 \%$ \\
Do “nothing” & $33 \%$ \\
Leisure activities & $9 \%$ \\
Other activities & $14 \%$ \\
\hline
\end{tabular}

Source: Unpublished surveys (2018; 2019).

While in the case of the students' moms, $100 \%$ of the interviewees stated that their mothers were the only ones responsible for the housework at home, including but not limited to: cleaning the house, doing the laundry, cooking, doing the dishes; some even said "she does everything at home" (P8, g; P16, b). Besides the housework, the students did not list any other activities that their mother developed when they were home.

When asked if they considered men and women to have the same rights, eleven (11) of thirteen (13) boys said "yes", and only two (2) of them said "no": those who believed men and women are endowed with the same rights did so because they considered them to be "equal" as human beings; those who disagreed did not know the reason to do so. On the other hand, twelve (12) of fourteen (14) girls also believed men and women share the same rights, while only two girls (2) stated that men and women do not have the same rights because "they do different things".

When asked what they considered to be the role of women in society, $\approx$ $23 \%$ of the boys answered that women are supposed to take care of the house; another $\approx 23 \%$ said women should work; $\approx 30 \%$ wrote: "I don't know"; $\approx 14 \%$ stated that women should work while at the same time take care of the family and do the housework; while $\approx 10 \%$ believe women should "marry and have children" $(\mathrm{P} 18, \mathrm{~b})$. When asked the same question, $\approx 28 \%$ of the girls wrote that women should work and build a family; $\approx 22 \%$ mentioned only work (as what women are supposed to do); $\approx 28 \%$ did not know what to answer; while 
$\approx 15 \%$ stated that women should stay home and take care of the children; one girl $(\approx 7 \%)$ answered that "besides cleaning the house, she [the woman] can also have a job” (P13, g).

\section{Discussion}

The results suggest that it can become very common for children to accept the existence of pre-assigned roles for men and women not only within the family core but also in society in general, as a result of the first (Marks, Bun \& McHale, 2009). As families constitute the first societal nucleus that children get in contact with, gender dynamics within the family core can indeed influence the perception of children over gender-assigned roles: which can result in repeating or not patterns of gender inequality and in reinforcing or challenging existing sociocultural practices (Leaper, 2014).

Firstly because there is still a gender gap between girls and boys within the family context, as boys enjoy more leisure time than girls and do not necessarily always help their parents with daily tasks, while even when girls do have free time they are not excused from helping their parents as opposed to some of the boys surveyed, in line with the literature that indicates that gender inequality patterns start as early as in childhood (Miller, 2018). And secondly, the results suggest very clearly the existence of an unequal balance in activity-distribution between men and women among the interviewees' households, just like other studies suggested before (e.g. in Kil, Neels \& Vergauwen, 2016): women are often the ones responsible for the housework, receiving no help at all from their husbands in 56\% of the times; and even though most of these mothers had a job, differently from men, they were not excused from performing domestic activities.

In this sense, feminist and gender education should aim - at least in the social and geographical context of this research - at helping these children challenge such preconceptions of gender-designated roles within their households, in order for the gender gap to be closed not only within the family context but as well as in society as a whole.

On the other hand, the majority of students, both boys and girls, believe that men and women indeed enjoy the same rights because they consider them to be "[...] equal human beings, independent from sex or skin colour" (P1, g). Even though this shows a somehow positive pattern amongst students' perception of rights-ownership, these children are taking into consideration 


\section{1 da Luz Scherf, Alves Lima Zanatta, Tumenas Mell - Gender-Awarness amongst Brazilian Children}

only the formal and not the substantial realm of the right to equality: men and women can (and should) enjoy equality under the law, but they might not do so in many other aspects of social life, such as within the household, as the previous results have demonstrated. The latest data reveals that at least four (4) women are killed every day in Brazil (Moloney, 2019), mostly resulting from domestic or intimate partner violence (Ally et al., 2016), therefore, these students should be taught that, despite the fact that men and women enjoy the same rights under the Constitution and other legislation, women are the ones more susceptible to abuse, violence and other kinds of rights violations.

The last results show that the perceptions of the children surveyed over gender-assigned roles and the place of women in society share a close link with the gender dynamics they witness at home: as all of their mothers are responsible for doing most of the housework at home, even when they do have a job. Thus, these students often internalize and perceive unequal power relations based on gender constructs as natural as opposed to socially and culturally constructed (Marks, Bun \& McHale, 2009).

The consequences are terrible: if both boys and girls grow up believing that women are naturally destined to marry, to have children, or to do all the housework alone even when they got a partner, we are fated to perpetuate patterns of gender inequality not only within the household but as well as in many other levels of society (Bhana, 2016). None of these children mentioned another role for women in society besides working or doing the housework: they did not mention their role in politics, in science, or any other maledominated fields, which especially in the girls' case can end up limiting the future visions they share of themselves.

Considering the downfall of gender education policies in contemporary Brazil (as previously argued), as well as the limitations to HRE in the country (Silva \& Tavares, 2013), this research appears as central to understanding both advancements and limitations of gender and feminist education in the context of primary education in Brazil, through the assessment of children's perceptions over "pre"-assigned gender roles and the place of women in society. If education - being so closely related to the exercise of civic life, citizenship and rights - does not confront gender-related issues, we are at great risk of reinforcing patterns of gender inequality and gender-based violence. 


\section{Conclusions}

Our main conclusions were that: a) gender dynamics within the family core influences a lot the perception of children over gender-assigned roles, which can result in repeating patterns of gender inequality and in reinforcing preassigned roles for women in society; b) the results have shown that most of the children surveyed believe men and women have the same rights, but on the other hand, when asked about what they considered to be the role of women in society, the majority answered that women should, besides having a job, be responsible for activities such as taking care of the house, of the children, doing housework and so forth. This vision imposes a burden upon girls and women to follow expected social roles that are often unjust and unequal (Marks, Bun \& McHale, 2009; Miller, 2018).

The role of gender education appears then as paramount in the task of helping these children challenge and question the unjust and unequal gender dynamics they witness at home. Latin America took a very long time to develop gender education policies, and gender-based violence is still very common in the region Lima (2016). Additionally, Brazil has witnessed the growth of ultra-conservatism in politics, which seriously undermines efforts to implement the diversity agenda in education (Hunter \& Power, 2019).

However, if these children grow up believing women are limited to certain roles in society, we are at great risk of depriving women and girls of their most fundamental rights and liberties (Campbell, 2016). That is the reason why all of those involved with education in Brazil cannot turn a blind eye to gender-related issues and should try to find ways of introducing the gender debate in the classroom despite the backward and conservative policies pushed by the current government.

Girls should be taught that they were not born into any specific role in society; that they have control over their own lives and can indeed picture different future scenarios from those experienced by their mothers (Leaper, 2014). Nevertheless, it can only happen through a combination of educational policies that focus on women's empowerment and educational programs that makes them aware of gender inequality and gender-based violence (Gill, Esson \& Yuen, 2016).

If primary education, as stated by Bhana (2016), is essential to contesting pre-assigned social roles for boys and girls because of their gender, 


\section{3 da Luz Scherf, Alves Lima Zanatta, Tumenas Mell - Gender-Awarness amongst Brazilian Children}

the results demonstrate how the schools (where the surveys took place) and how the teachers have failed to introduce the gender debate in the classroom.

Regarding the limitations of the study and future perspectives, two points should be made related to: a) the geographical scope of the research; and the b) research sampling. The geographical scope of the research could not be expanded due to the amount of (economic and human) resources we had at our disposal. We also ended up with a smaller sample than we predicted, which poses a limitation to the development of a large-scale longitudinal research design. However, we believe that our sampling was enough to provide a solid background on how children in different cities from a Brazilian state, enrolled in primary education, perceive gender-related issues, especially the role of women in the family context as well as in society. This inquiry encourages the development of other empirical researches in Brazil, that focus on gender education outcomes and bring up the barriers still needed to be overcome regarding gender and feminist education in the country.

\section{References}

Aikman, S., \& Unterhalter, E. (2007). Practising Gender Equality in Education. Oxford: Oxfam GB.

Aksornkool, N. (1995). Educate to Empower. In C. Medel-Anonuevo (Ed.), Women, Education and Empowerment: Pathways towards Autonomy (pp. 53-62). Hamburg: UNESCO Institute for Education.

Ally, E. Z., Laranjeira, R., Viana, M. C., Pinsky, I., Caetano, R., Mitsuhiro, S., \& Madruga, C. S. (2016). Intimate partner violence trends in Brazil: Data from two waves of the Brazilian National Alcohol and Drugs Survey. Revista Brasileira de Psiquiatria, 38(2), 98-105. http://dx.doi.org/10.1590/1516-4446-2015-1798

Balieiro, F. D. (2017). A “guerra” contra o gênero: Reações às últimas décadas de políticas de promoção da igualdade de gênero no Brasil (The "war" on gender: Reactions to the last decades of policies aiming to promote gender equality in Brazil). Cadernos Pagu, 51, 1-9. http://dx.doi.org/10.1590/18094449201700510022

Barreiro, A., \& Martins, F. H. (2016). Bases e fundamentos legais para a discussão de gênero e sexualidade em sala de aula (Bases and legal foundations for the discussion of gender and sexuality in the 
classroom). Leitura: Teoria \& Prática, 34(68), 93-106. Retrieved from https://ttp.emnuvens.com.br/ltp/article/view/535

Bastos, P. P. (2017). Ascensão e crise do governo Dilma Rousseff e o golpe de 2016: poder estrutural, contradição e ideologia (The rise and fall of Dilma Rousseff government and the 2016 coup: structural power, contradiction and ideology). Revista de Economia Contemporânea, 21(2). https://doi.org/10.1590/198055272129

Bhana, D. (2016). Gender and Childhood Sexuality in Primary School. Singapore: Springer.

Bhat, R. A. (2015). Role of Education in the Empowerment of Women in India. Journal of Education and Practice, 6(10), 188-191. Retrieved from https://files.eric.ed.gov/fulltext/EJ1081705.pdf

Braz, M. (2017). O golpe nas ilusões democráticas e a ascensão do conservadorismo reacionário (The coup in democratic illusions and the rise of reactionary conservatism). Serviço Social \& Sociedade, 128, 85103. https://doi.org/10.1590/0101-6628.095

Brazilian Ministry of Education (MEC). (2013). Diretrizes Curriculares Nacionais da Educação Básica (Brazilian Curriculum Guidelines for Primary Education). Brasília: MEC.

Campbell, M. (2016). The challenges of girls' right to education: Let's talk about human rights-based sex education. The International Journal of Human

Rights, 20(8), 1219-1243.

https://doi.org/10.1080/13642987.2016.1207627

Cioccari, D., \& Persichetti, S. (2018). Armas, ódio, medo e espetáculo em Jair Bolsonaro (Guns, hatred, fear and spectacle in Jair Bolsonaro). Revista Alterjor, 18(2), 201-214. $\quad$ Retrieved from http://www.revistas.usp.br/alterjor/article/view/144688

Creswell, J. W. (2014). Research design: Qualitative, quantitative, and mixed methods approaches (4th ed.). Los Angeles: SAGE Publications. Ebook.

Dsouza, M. O. (1992). Philosophy, philosophy of education, and the education of teachers. Interchange, 23(3), 255-264. https://doi.org/10.1007/BF00364546

Finguerut, A., \& Souza, M. A. (2018). Que Direita É Esta? As Referências A Trump Na Nova Direita Brasileira Pós-Michel Temer (What right-wing is this? References to Trump in the Brazilian new right-wing after 
45 da Luz Scherf, Alves Lima Zanatta, Tumenas Mell

- Gender-Awarness amongst Brazilian Children

Michel Temer). Revista TOMO, 33, 229-269. https://doi.org/10.21669/tomo.v0i33.9357

Fortunato, I., \& Dias, A. M. (2018). Gender issues and education: State of research in Brazil. Policy Futures in Education, 16(5), 620-631. https://doi.org/10.1177/1478210318789239

Gill, J., Esson, K., \& Yuen, R. (2016). A Girl's Education: Schooling and the Formation of Gender, Identities and Future Visions. London: Palgrave Macmillan.

Gonçalves, R., \& Abreu, S. (2018). Do plano nacional de políticas para as mulheres ao "machistério" de Temer (From the national policies plan for women to the "machistério" of Temer). Revista de Políticas Públicas, 22(2), 753-771. http://dx.doi.org/10.18764/21782865.v22n2p753-771

Gottesman, I. (2016). The critical turn in education: From Marxist critique to poststructuralist feminism to critical theories of race. New York: Routledge.

Guilherme, A. A., \& Picoli, B. A. (2018). Escola Sem Partido/School Without Party - totalitarian elements in a modern democracy: Some reflections based on Arendt. Revista Brasileira de Educação, 23, 1-23. http://dx.doi.org/10.1590/s1413-24782018230042

Hunter, W., \& Power, T. J. (2019). Bolsonaro and Brazil's Illiberal Backlash. Journal of Democracy, 30(1), 68-82. https://doi.org/10.1353/jod.2019.0005

Jalalzai, F., \& Santos, P. G. (2015). The Dilma Effect? Women's Representation under Dilma Rousseff's Presidency. Politics \& Gender, 11(01), 117-145. https://doi.org/10.1017/s1743923x14000579

Kil, T., Neels , K., \& Vergauwen, J. (2016). Gender inequality in the division of housework over the life course: a European comparative perspective. In D. Mortelmans (Ed.), Changing Family Dynamics and Demographic Evolution (pp. 51-80). Cheltenham: Edward Elgar Publishing. https://doi.org/10.4337/9781785364983.00010

Kincheloe, J. L. (2007). The Vicissitudes of Twenty-First Century Critical

Pedagogy. Studies in Philosophy and Education, 27(5), 399-404. https://doi.org/10.1007/s11217-007-9084-9

Leaper, C. (2014). Parents' Socialization of Gender in Children. Encyclopedia on Early Childhood Development. Retrieved from: http://www.child- 
GÉNEROS -Multidisciplinary Journal of Gender Studies, 9(1) 46

\section{encyclopedia.com/gender-early-socialization/according- experts/parents-socialization-gender-children}

Lima, M. S. (2016). Políticas de educação que tratam de gênero e sexualidades na América Latina: Um Estudo sobre Brasil e Uruguai (Education policies that cover gender and sexuality in Latin America: A Study about Brazil and Uruguay) (Masters dissertation). Retrieved from: https://repositorio.ufpe.br/handle/123456789/24257

Lingard, B., Henry, M., \& Taylor, S. (1987). 'A Girl in a Militant Pose': A chronology of struggle in girls' education in Queensland. British Journal of Sociology of Education, 8(2), 135-152. https://doi.org/10.1080/0142569870080203

Londoño, E., \& Andreoni, M. (2018, October). Brazil Election: How Jair Bolsonaro Turned Crisis Into Opportunity. The New York Times. Retrieved

from https://www.nytimes.com/2018/10/29/world/americas/jair-bolsonarobrazil-profile.html

Macaulay, F. (2006). Gender Politics in Brazil and Chile: The Role of Parties in National and Local Policymaking. New York: Palgrave Macmillan.

Machado, M. D. (2018). Religion and moral conservatism in Brazilian politics. Politics and Religion Journal, 12(1), 55-74. Retrieved from https://www.politicsandreligionjournal.com/index.php/prj/article/view 1288

MacNaughton, G. (2000). Rethinking Gender in Early Childhood Education. St Leonards: Allen \& Unwin.

Marchionni, M., Gasparini, L., \& Edo, M. (2018). Brechas de género en América Latina: Un estado de situación. Caracas: Banco de Desarollo de América Latina.

Marczyk, G., DeMatteo, D., \& Festinger, D. (2005). Essentials of research design and methodology. New Jersey: John Wiley \& Sons.

Marks, J. L., Lam, C. B., \& Mchale, S. M. (2009). Family Patterns of Gender Role Attitudes. Sex Roles, 61(3-4), 221-234. http://dx.doi.org/10.1007/s11199-009-9619-3

Mayo, C. (2013). Gender Disidentification: The Perils of the Post-Gender Condition. In B. J. Thayer-Bacon, L. Stone, \& K. M. Sprecher (Eds.), Education feminism: Classic and contemporary readings (pp. 243252). Albany: State University of New York Press. 
47 da Luz Scherf, Alves Lima Zanatta, Tumenas Mell

- Gender-Awarness amongst Brazilian Children

Mayo, P. (2006). Critical Pedagogy for Transformative Optimism. Interchange, 37(3), 277-283. https://doi.org/10.1007/s10780-0069004-X

McCracken, K., Unterhalter, E., Márquez, S., \& Chełstowska, A. (2015). Empowering women and girls through education. Retrieved from http://www.europarl.europa.eu/RegData/etudes/STUD/2015/510022/I POL_STU(2015)510022_EN.pdf Document requested by the Committee on Women's Rights and Gender Equality

Meredith, S. (2018, October). Who is the 'Trump of the Tropics?': Brazil's divisive new president, Jair Bolsonaro- in his own words. CNBC. Retrieved from https://www.cnbc.com/2018/10/29/brazil-election-jairbolsonaros-most-controversial-quotes.html

Miller, C. C. (2018, August 8). A ‘Generationally Perpetuated' Pattern: Daughters Do More Chores. The New York Times. Retrieved from https://www.nytimes.com/2018/08/08/upshot/chores-girls-researchsocial-science.html

Miskolci, R., \& Campana, M. (2017). "Ideologia de gênero": Notas para a genealogia de um pânico moral contemporâneo ("Gender ideology”: Notes for a genealogy of a contemporary moral panic). Sociedade $e$ Estado, 32(3), 725-748. http://dx.doi.org/10.1590/s010269922017.3203008

Moloney, A. (2019, February). 4 women killed every day in Brazil in 2019, human rights body reports. Retrieved from https://womenintheworld.com/2019/02/05/4-women-killed-every-dayin-brazil-in-2019-human-rights-body-reports/

National Congress. (2019, January 1). Discurso do Presidente da República, Jair Bolsonaro, durante Cerimônia de Posse no Congresso Nacional (Speech by the President of the Republic, Jair Bolsonaro, during the Inauguration Ceremony in Congress). Retrieved from http://www2.planalto.gov.br/acompanhe-o-

planalto/discursos/2019/discurso-do-presidente-da-republica-jair-

bolsonaro-durante-cerimonia-de-posse-no-congresso-nacional

Ng, R. (1995). Teaching against the Grain: Contradictions and Possibilities. In R. Ng, P. Staton, \& J. Scane (Eds.), Anti-racism, feminism, and critical approaches to education (pp. 129-152). Westport: Bergin \& Garvey. 
Oliveira, A. D. C. et al. (2014). O portal do Caderno de Cidadania como ferramenta de inclusão digital (The Citizenship Notebook portal as a tool for digital inclusion). Revista Brasileira de Tecnologias Sociais, 1(2), 43-54. http://dx.doi.org/10.14210/rbts.v1n2.p43-54

Pappas, E. C., \& Garrison, J. W. (1991). Towards a new philosophy of education: Extending the conversational metaphor for thinking. Studies in Philosophy and Education, 10(4), 297-314. https://doi.org/10.1007/BF00364546

Phillips, T., \& Kaiser, A. J. (2019, April). Brazil must not become a 'gay tourism paradise', says Bolsonaro. The Guardian. Retrieved from https://www.theguardian.com/world/2019/apr/26/bolsonaro-accusedof-inciting-hatred-with-gay-paradise-comment

Reis, T., \& Eggert, E. (2017). Ideologia de gênero: uma falácia construída sobre os planos de educação brasileiros (Gender ideology: A fallacy built around the Brazilian Education Plans). Educação \& Sociedade, 38(138), 9-26. http://dx.doi.org/10.1590/es0101-73302017165522

Roos, P. A., \& Gatta, M. L. (2009). Gender (in)equity in the academy: Subtle mechanisms and the production of inequality. Research in Social Stratification and Mobility, 27(3), 177-200. https://doi.org/10.1016/j.rssm.2009.04.005

Ruschel, C. V., Aguiar, M. L., Schuller, N. T., \& Luiz, P. C. (2018). Direito à educação ecológica: a experiência do projeto de extensão 'Direito intergeracional e Transversalidade da UNIVALI' (The right to an ecological education: the experience of the research project 'Intergenerational Law \& Transversality' from UNIVALI). Cataventos, 10(2), 67-81. Retrieved from http://revistaeletronica.unicruz.edu.br/index.php/Cataventos/article/vie w/6871/1743

Schugurensky, D., \& Myers, J. P. (2003). Citizenship Education: Theory, Research and Practice. Encounters in Theory and History of Education, 4, 1-10. http://dx.doi.org/10.24908/eoe-ese-rse.v4i0.655

Seisdedos, S. R., \& Bonometti, P. (2010). Las mujeres en América Latina: indicadores y datos (Women in Latin America: main indicators and facts). Rev. Ciencias Sociales, 127(6), 75-87.

Silva, A. M., \& Tavares, C. (2013). Educação em direitos humanos no Brasil: Contexto, processo de desenvolvimento, conquistas e limites (Human rights education in Brazil: Context, development process, achievements 
49 da Luz Scherf, Alves Lima Zanatta, Tumenas Mell

- Gender-Awarness amongst Brazilian Children

and limits). Educação (Porto Alegre), 36(1), 50-58. Retrieved from http://revistaseletronicas.pucrs.br/ojs/index.php/faced/article/view/123 $15 / 8740$

Somani, T. (2017). Importance of Educating Girls for the Overall Development of Society: A Global Perspective. Journal of Educational Research and Practice, 7(1), 125-139. Retrieved from https://scholarworks.waldenu.edu/jerap/vol7/iss1/10/

Struthers, A. E. (2014). Human rights education: Educating about, through and for human rights. The International Journal of Human Rights, 19(1), 53-73. http://dx.doi.org/10.1080/13642987.2014.986652

Tibbitts, F. L. (2015). Women's human rights education trainers in Turkey: Situated empowerment for social change. Journal of Peace Education, 13(1), 41-59. http://dx.doi.org/10.1080/17400201.2015.1103722

UNESCO (2008). A View Inside Primary Schools: A World Education Indicators (WEI) cross-national study. Montreal: UNESCO Institute for Statistics.

UNICEF (2018, June). Gender and education. Retrieved from https://data.unicef.org/topic/gender/gender-disparities-in-education/

United Nations High Commissioner for Human Rights (2017). Realisation of the equal enjoyment of the right to education by every girl. Retrieved from

https://www.right-to-education.org/sites/right-toeducation.org/files/resource-

attachments/OHCHR_Report_Girls_Equal_Right_Education_2017_E n.pdf

Winslow, S. (2010). Gender inequality and time allocations among academic faculty. Gender and Society, 24(6), 769-793. Retrieved from http://www.jstor.org/stable/25789906 
GÉNEROS -Multidisciplinary Journal of Gender Studies, 9(1) 50

Erick da Luz Scherf University of Itajaí Valley, Brazil

E-mail address: erickscherf@gmail.com

Maria de Lourdes Alves Lima Zanatta University of Itajaí Valley, Brazil

E-mail address: maludireito@gmail.com

Estefania Tumenas Mello University of Itajaí Valley, Brazil

E-mail address: estefania@univali.br. 